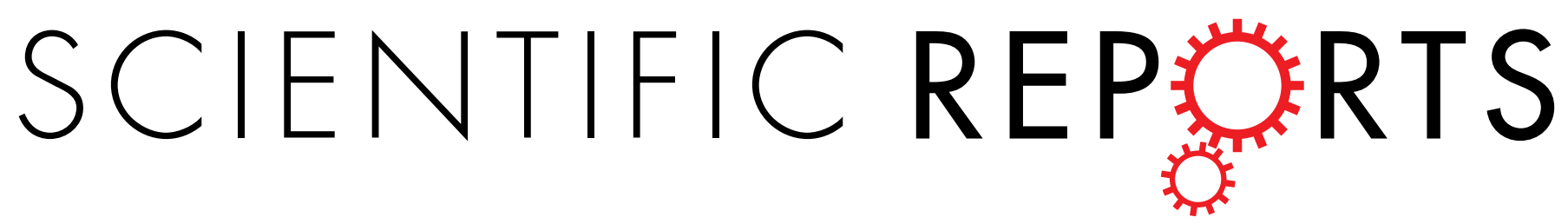

\title{
OPEN Erratum: Weibel-Palade body size modulates the adhesive activity of its von Willebrand Factor cargo in cultured endothelial cells
}

Francesco Ferraro, Mafalda Lopes da Silva, William Grimes, Hwee Kuan Lee, Robin Ketteler, Janos Kriston-Vizi \& Daniel F. Cutler

Scientific Reports 6:32473; doi: 10.1038/srep32473; published online 31 August 2016; updated on 26 September 2016

The original version of this Article contained a typographical error in the spelling of the author Mafalda Lopes da Silva which was incorrectly given as Silva Mafalda Lopes da. This has now been corrected in the PDF and HTML versions of the Article.

(c) (i) This work is licensed under a Creative Commons Attribution 4.0 International License. The images or other third party material in this article are included in the article's Creative Commons license, unless indicated otherwise in the credit line; if the material is not included under the Creative Commons license, users will need to obtain permission from the license holder to reproduce the material. To view a copy of this license, visit http://creativecommons.org/licenses/by/4.0/

(C) The Author(s) 2016 